\title{
Interactions of trace metals and different marine food chains
}

\author{
Wen-Xiong Wang* \\ Department of Biology, The Hong Kong University of Science and Technology (HKUST), Clear Water Bay, Kowloon, \\ Hong Kong, PR China
}

\begin{abstract}
There is increasing recognition of the quantitative importance of metal accumulation from dietary pathways in different marine food webs. With a simple kinetic model requiring measurements of metal assimilation efficiency (AE), metal efflux rate and ingestion activity of the relevant animals, it is possible to predict the transfer (and potential biomagnification) of metals along diverse marine food chains. In this paper, food chain transfer in different marine food chains (planktonic and benthic) is reviewed, and any potential biomagnification of metals is predicted using the simple kinetic equation. It is well recognized that metal concentrations in animals are probably not related to the trophic level in the food chain, but some metals ( $\mathrm{Hg}$ and $\mathrm{Zn}$ ) may potentially be influenced by the numbers of trophic interactions involved. Depending on these different trophic interactions, the potential biomagnification of metals is influenced by metal assimilation or metal efflux rate or both. Metals may potentially be biomagnified in benthic food chains; principally, in those with gastropods as top predators, as they can efficiently sequester dietary metals. The biodiminution of metals (concentration decreases at a higher trophic level) in the classical marine planktonic food chain (phytoplankton to copepods to fish) is largely the result of the effective efflux of metals by the copepods and the very low assimilation of metals by marine fish. Although many past studies have considered the physico-chemical properties of metals in prey in controlling food chain transfer, it is suggested that the physiological and biochemical processes in the herbivore or predator should be emphasized in future studies. Also, the complicated metal-handling strategies found in different marine organisms clearly need to be appreciated.
\end{abstract}

KEY WORDS: Food chain · Trace metals · Biomagnification · Trophic transfer factor · Invertebrates · Fish

\section{INTRODUCTION}

The food chain transfer of metal contaminants has been considered in studies dating back to the 1960s (Bryan 1979, Fowler 1982). The Minamata incident, which occurred in the 1950s in Japan as a result of $\mathrm{Hg}$ contamination (involving methylation and food contamination), raised substantial concerns about the transfer of metal contaminants in marine food webs and their access to the human one, and was the starting point for many ecotoxicological studies. Ecological risk

*Email: wwang@ust.hk assessment is thus concerned with whether such chemical contaminants can pose risks to aquatic organisms and humans as a result of chemical exposure, including via dietary ingestion. There were extensive studies in the 1970s on the transfer of radionuclides in marine food webs (Pentreath 1977, Fowler 1982). Many of these studies were concerned with the bioaccumulation of radionuclides from dissolved and food sources (Fowler 1982, Bryan 1984). Factors affecting metal bioaccumulation from the aqueous phase have been extensively researched. Equilibrium was an important principle underlying these earlier studies, although it was also well recognized that equilibrium can be diffi- 
cult to reach for most aquatic organisms if not entirely impossible, except for unicellular algae or other small organisms with a short generation time (Fisher \& Reinfelder 1995, Wang \& Fisher 1999). Over the past decade, there has been an increasing awareness of the significance of kinetics in metal accumulation in aquatic organisms (e.g. Luoma \& Fisher 1997). Several kinetic parameters have now been developed to quantify metal uptake and bioavailability from different sources (e.g. aqueous and dietary sources), and these parameters are being better defined and studied extensively. These parameters include the metal assimilation efficiency (AE) from a food source, defined as the fraction of metal incorporated into animal tissue after initial absorption across the gut lining following digestion, the metal influx rate or rate constant, and the metal efflux rate constant $\left(\mathrm{k}_{\mathrm{e}}\right)$, defined as the rate constant of loss of metals from animal soft tissue by physiological elimination.

In this review, recent progress in studying the food chain transfer of trace metals in different ecological marine food chains is summarized. Earlier experimental studies have examined the trophic transfer of metals in aquatic food chains (Fowler 1982, Bryan 1984, Fisher \& Reinfelder 1995, Nott 1998). Recent studies have, however, made major progress in this research field, largely as a result of the development of novel approaches to quantifying metal bioavailability from dietary sources. Several paradigms underlying metalfood web interaction in marine ecosystems have emerged through studies of different marine food webs. This review mainly considers 2 major parameters significant in controlling metal food chain transfer in marine animals, namely metal AE from ingested food and metal efflux from animals during physiological turnover. The trophic transfer factor is then modeled under various conditions for different metals in various marine food chains. Metal complexity (different metal behavior) and food web complexity (different food chains or webs) are both highlighted in the review, and the gaps in our current knowledge in this research field are pointed out.

\section{TRACE METAL CONCENTRATION AND BIOACCUMULATION AT DIFFERENT MARINE TROPHIC LEVELS}

Numerous studies have quantified metal concentrations in different marine organisms at different trophic levels (summarized in Eisler 1981, Bryan 1984, Rainbow 1993, Kennish 1997). There are tremendous variations (e.g. over orders of magnitude) in metal concentrations both intra- and interspecifically. A great challenge for metal biologists and ecotoxicologists is thus to understand and predict the significance of metal concentrations in these diverse aquatic animals and the processes pertaining to such concentrations (Rainbow 1993). For example, concentrations of Ag, $\mathrm{Cd}, \mathrm{Cu}$, and $\mathrm{Zn}$ were 16, 2, 32 and $40 \times$ higher in American oyster Crassostrea virginica than in mussel Mytilus edulis collected from the same locations (Long Island Sound, $\mathrm{NY}$ ); while, $\mathrm{Cr}, \mathrm{Pb}$ and Se concentrations were 5, 3.5 and $1.6 \times$ higher in the mussels than in the oysters (O'Connor 1992). Zn concentrations in the gastropod Morula musiva were about $10 \times$ higher than its concentration in another gastropod, Thais luteostoma, collected from the same locations (Blackmore \& Morton 2001), but the Cd concentrations in these 2 species were similar. Although there is no general rule that predicts whether or not trace metal is biomagnified along a marine food chain, the concentration of $\mathrm{Cd}$ generally decreases at higher trophic levels in classic planktonic food webs (e.g. phytoplankton to zooplankton to fish), whereas $\mathrm{Hg}$ concentrations increase at higher trophic levels (Bryan 1984, Kennish 1997). However, exceptions always exist and clearly, metal concentrations depend on the strategies of physiological accumulation used by specific animals. For example, planktonic hyperiid amphipods and deepsea caridean decapods have far higher Cd concentrations than the zooplankton on which they feed (Ridout et al. 1985, White \& Rainbow 1987, Rainbow 1989).

Recently, Chen et al. (2000) analyzed concentrations of $\mathrm{Hg}, \mathrm{Zn}, \mathrm{Cd}, \mathrm{As}$ and $\mathrm{Pb}$ from 20 lakes in contaminated to pristine watersheds in the NE USA. They provided field evidence for the biomagnification of $\mathrm{Hg}$ and $\mathrm{Zn}$ from the small plankton (45 to $202 \mu \mathrm{m}$ ) to macrozooplankton (>202 $\mu \mathrm{m})$ and from the macrozooplankton to fish in these lake systems. Concentrations of $\mathrm{Hg}$ and $\mathrm{Zn}$ in the zooplankton were predictive of $\mathrm{Hg}$ and $\mathrm{Zn}$ levels in the fish. Both As and $\mathrm{Pb}$ were diminished with increasing trophic level, and despite the pronounced difference in As concentration in zooplankton between the pristine and contaminated lakes, the biodiminution resulted in a comparable concentration in fish across the different sites (Chen \& Folt 2000). In a marine benthic community, however, concentrations of $\mathrm{Cd}, \mathrm{Cu}$ and $\mathrm{Zn}$ in predatory gastropods generally increase when compared with their preys' (Blackmore 2000, Jeng et al. 2000). Whereas there is no evidence indicating a general rule about the biomagnification of trace metals across different trophic levels (benthic or planktonic), there does appear to be a difference in metal transfer along different marine food chains. Understanding the differences in metal transfer among contrasting marine food webs presents a great dilemma to metal ecotoxicologists.

The influence of food web dynamics on metal concentrations in freshwater systems has recently been 
emphasized (Stemberger \& Chen 1998, Chen et al. 2000). Stemberger \& Chen (1998) indicated that Zn and $\mathrm{Hg}$ concentrations in freshwater lake fish were significantly and positively correlated with the chain length of the zooplankton web. Complex food webs may attenuate the transfer of metals to the higher trophic levels, and the high variability of metal concentrations in fish observed among different systems may be partly explained by the structural features of the plankton webs. Increasing the food web complexity may have introduced more variables into the chances of biomagnification. This is mainly caused by the complexity of metal-handling strategies in different groups of marine organisms. For example, several studies have highlighted the control of metal binding with insoluble ligands as affecting their availability to the predators (Nott \& Nicolaidou 1990, Amiard-Triquet et al. 1993, Nott 1998, Ettajani et al. 2001).

Various models have now been developed to quantify the rate of contaminant bioaccumulation in aquatic ecosystems (Spacie \& Hamelink 1985, Landrum et al. 1992, Newman 1995). Kinetic modeling of the different compartments of metal bioaccumulation was first developed by pharmacologists and radioecologists dating back to the 1950s. Thomann (1981) proposed a kinetic model incorporating metal uptake from both aqueous and dietary phases, in which the uptake rate was predicted by first-order kinetics. Such a kinetic model provides a general framework to study the bioaccumulation of metals in aquatic organisms, but the processes controlling the parameters are complex. Under steady state conditions, metal concentration in animals $\left(\mathrm{C}_{\mathrm{n}, \mathrm{f}}\right.$ $\mu \mathrm{g} \mathrm{g}^{-1}$ ), resulting from accumulation from the lower trophic levels, can be calculated by a simple mathematical equation:

$$
\mathrm{C}_{\mathrm{n}, \mathrm{f}}=\frac{\left(\mathrm{AE} \times \mathrm{IR} \times \mathrm{C}_{\mathrm{n}-1}\right)}{\mathrm{k}_{\mathrm{e}}}
$$

where IR is the ingestion rate of the animal (\% body weight $\left.\mathrm{d}^{-1}\right), \mathrm{C}_{\mathrm{n}-1}$ is the metal concentration in ingested prey $\left(\mu \mathrm{g} \mathrm{g}^{-1}\right.$ ) and $\mathrm{k}_{\mathrm{e}}$ is measured per day.

Thus, the food chain transfer factor (TTF) is:

$$
\mathrm{TTF}=\mathrm{C}_{\mathrm{n}, \mathrm{f}} / \mathrm{C}_{\mathrm{n}-1}=(\mathrm{AE} \times \mathrm{IR}) / \mathrm{k}_{\mathrm{e}}
$$

With such a simple mathematical equation, the trophic interaction of a metal can therefore be quantified by 3 parameters: $\mathrm{AE}, \mathrm{IR}$ and $\mathrm{k}_{\mathrm{e}}$. AE $\times \mathrm{IR}$ can be considered as the uptake rate constant from the dietary phase, and thus TTF is analogous to the bioconcentration factor (BCF) currently used to describe the extent to which a metal can be concentrated by an organism from ambient dissolved seawater. However, in contrast to BCFs, TTF remains mostly unknown for most preypredator relationships. A value of TTF $>1$ would indicate the possibility of biomagnification (over these 2 trophic levels in the food chain), whereas a value of $<1$ would indicate a biodiminution when the metal is transferred from the lower trophic level $(\mathrm{n}-1)$ to the higher trophic level (n).

Conclusions regarding biomagnification are generally based on comparing metal concentrations in whole individual bodies from different animals (Bryan 1979). Comparisons of different tissues can sometimes be misleading, because metals are known to concentrate in a specific organ or tissue (e.g. the kidneys). Furthermore, biomagnification defined by comparing metal concentrations or bioconcentration factors (or bioaccumulation factors) at different trophic levels can often mislead, because trophic transfer is often assumed when metal concentrations at different levels are compared. A higher bioconcentration factor at higher trophic levels may result from a higher ability to accumulate a metal from the aqueous phase compared to lower trophic levels, instead of solely the uptake of a metal from the prey organism. Such comparisons have, however, been used in many studies to demonstrate whether a metal has been biomagnified or not (e.g. Suedel et al. 1994). It is clear from this analysis that the route of metal exposure is the basis for a further understanding of metal transfer in marine food chains. For example, Amiard-Triquet et al. (1980) compared $\mathrm{Cd}, \mathrm{Pb}, \mathrm{Cu}$ and $\mathrm{Zn}$ in neritic and estuarine planktonic trophic levels (planktivorous fish and their prey, mainly copepods and mysids). Trace element concentrations in organisms from different steps in the food chain were compared using the TTF (concentration in the consumer/concentration in the prey). It was generally $<1$ for $\mathrm{Cd}, \mathrm{Pb}$ and $\mathrm{Cu}$ but often $>1$ for $\mathrm{Zn}$. The level of $\mathrm{Zn}$ in the predator used for the calculation of TTF, however, resulted from uptake both from food and water.

A theoretical treatment of potential biomagnification of metals in marine food chains involves incorporating 3 parameters (AE, IR, and $k_{e}$ ) into the food chain TTF. There has been some indication that differences in $\mathrm{AE}$ between organic and inorganic metal species may largely account for the differences in their potential biomagnification (Hodson 1980, Fowler 1985). Reinfelder et al. (1998) have taken this concept further and proposed scenarios under which metals are likely to be biomagnified or biodiminished in marine copepods, bivalves and fish. For example, they predicted biomagnification of methylmercury largely as a result of its high $\mathrm{AE}$ and low $\mathrm{k}_{\mathrm{e}}$. However, a general pattern is lacking because many of the parameters were not available for modeling in fish and the ingestion rate of the animals (which is critical for modeling biomagnification) remains uncertain.

Amiard-Triquet et al. (1993) suggested that in many cases metal concentrations in animals are not related to the trophic level in the food chain, but are dependent on the physiological characteristics of the species 
or populations as well as the biological role of each element. Complicated feeding behavior (e.g. prey specificity, which affects $A E, I R$, and $k_{e}$ ) further renders it difficult to model the food chain transfer of metals through different trophic levels. Thus, the physicochemical state of the accumulated metals and the associated method of detoxification (granules or metalloproteins) have a much greater influence on the concentrations of metals in different marine species, and trophic transfer is more species-specific and concentration-specific rather than trophic level-specific (Ettajani \& Pirastru 1992). It is thus difficult to generalize about metal transfer along marine food chains based on the analysis of different trophic levels. Instead, it is necessary to examine the distribution of stored accumulated metal between soluble forms (e.g. metalloproteins) or insoluble forms (e.g. granules). The chemical form or digestibility of the stored metaliferous compounds is the key to predicting their potential for food chain transfer (Amiard-Triquet et al. 1992).

\section{TRANSFER FROM PHYTOPLANKTON TO ZOOPLANKTON AND FISH}

The assimilation of metals by marine zooplankton from ingested phytoplankton has been investigated extensively over the past 10 yr (e.g. Fisher \& Reinfelder 1991, Reinfelder \& Fisher 1991, Wang et al. 1996b, Wang \& Fisher 1998, Xu \& Wang 2001). Early experimental studies demonstrated that metal assimilation in marine copepods is directly related to the nature of metal partitioning in the cytoplasm of ingested phytoplankton (Reinfelder \& Fisher 1991, Hutchins et al. 1995). The 'liquid' digestion hypothesis implies a simple digestive process for copepods characterized by a short gut passage time (GPT). A recent study, however, demonstrated that the metal AEs by the copepod Acartia spinicauda from the diatom cell walls or fecal pellets produced by copepods were in fact very comparable to the metal AEs measured for various living phytoplankton cells, and adds another paradigm for metal transfer through copepods. For example, metals egested with faecal pellets can be assimilated by the copepod Acartia spinicauda with relatively high efficiency ( 47 to $54 \%$ for Cd, 30 to $43 \%$ for Se and 43 to $46 \%$ for Zn; Xu \& Wang 2002a). Metals associated with the cell wall of diatoms Thalassiosira weissflogii and Thalassiosira rotula were assimilated by copepods with an efficiency of 71 to 81,57 to 59 and 46 to $48 \%$ for $\mathrm{Cd}$, Se and Zn, respectively.

Many environmental and food conditions play a role in determining metal assimilation. It is important to realize that such influences may not be caused by a change in metal physico-chemical behavior. An early study demonstrated that food quantity did not affect the assimilation of several trace elements $(\mathrm{Cd}, \mathrm{Se}, \mathrm{Zn}$ and Co) by copepods (Wang et al. 1996b); however, a more recent study on individual copepods clearly showed that assimilation of metals increased with a decrease in food abundance (Xu \& Wang 2001). Digestion was also controlled by the rate at which a metal passed through the digestive tract. Variability of metal AEs among different food types appears to be less significant as compared to the inter-metal variation of AEs. Wang et al. (1996b) found that Zn AEs ranged between 65 and $80 \%$ for different phytoplankton species (green algae, diatoms, dinoflagellates). Among the 2 diatom diets and natural seston examined by Wang \& Fisher (1998), there were no major differences in metal AEs by the marine copepod Temora longicornis. Chang \& Reinfelder (2000) found that the AE of $\mathrm{Cu}$ by the copepod Acartia tonsa fed with the diatom Thalassiosira weissflogii increased from 40 to $50 \%$ when the $\mathrm{Cu}$ free ion concentration increased from $10^{-12.79}$ to $10^{-10.79} \mathrm{M}$.

The nature of the physiological and biochemical controls on metal assimilation by marine copepods remains largely unknown at present. $\mathrm{Xu}$ \& Wang (2001) have shown that the metal AE increased with increasing GPT until it reached a certain value, beyond which the AE was relatively independent of the GPT. Furthermore, the metal GPT is much longer than the food GPT because of the complicated digestive and chemical process occurring in the gut (e.g. desorption and re-sorption). This further implies that metals are subject to somewhat more vigorous digestion within the copepod gut than food particles (Wang \& Fisher 1998, Xu \& Wang 2001). A recent study has demonstrated the presence of metallothioneins binding with metals in a benthic copepod Tigriopus brevicornis in polluted waters (Barka et al. 2001), but whether the metallothioneins can affect metal assimilation in copepods has not been demonstrated.

Several studies have directly measured the actual metal loss from copepods following different routes of uptake (Wang \& Fisher 1998, Xu et al. 2001). For example, the $\mathrm{k}_{\mathrm{e}}$ measured in a temperate copepod (Temora longicornis) were 0.108 to $0.297,0.155$ and 0.079 to $0.108 \mathrm{~d}^{-1}$ for $\mathrm{Cd}$, Se and $\mathrm{Zn}$, respectively. The $\mathrm{k}_{\mathrm{e}}$ of $\mathrm{Cu}$ in different species of marine copepods was somewhat comparable (0.05 to $0.08 \mathrm{~d}^{-1}$; Ritterhoff \& Zauke 1997 , Chang \& Reinfelder 2002). In tropical and subtropical regions, in which small copepods are dominant, $\mathrm{k}_{\mathrm{e}} \mathrm{s}$ are somewhat higher than those measured in temperate regions. The $\mathrm{k}_{\mathrm{e}} \mathrm{s}$ measured in a subtropical copepod Acartia spinicauda were 0.55 to $0.60,0.67$ to 0.9 and 0.58 to $0.62 \mathrm{~d}^{-1}$ for $\mathrm{Cd}, \mathrm{Se}$ and $\mathrm{Zn}$, respectively. It is unknown whether the high elimination rate (efflux rate) is entirely due to the differences in body size or 
temperature. However, metabolic activity appears to have no major influence on the $\mathrm{k}_{\mathrm{e}} \mathrm{s}$ of essential metals, such as Se and Zn. When quantified at different food concentrations, for example, there was little variation in the $\mathrm{k}_{\mathrm{e}} \mathrm{s}$ of these metals in copepods (Wang \& Fisher 1998). Because the $\mathrm{k}_{\mathrm{e}} \mathrm{s}$ are so high, a biodiminution of metals when they are transferred from primary producers to zooplankton is expected.

Using Eq. (2), it is then possible to model the potential food chain TTF in copepods (Fig. 1), using an approach similar to that proposed by Reinfelder et al. (1998). The AEs and $k_{e}$ are available for 2 copepod species (temperate Temora longicornis and subtropical Acartia spinicauda) (Wang \& Fisher 1998, Xu et al. 2001). Both the low (20\% body dry wt $\mathrm{d}^{-1}$ ) and high ( $60 \%$ body dry wt $\mathrm{d}^{-1}$ ) ends of ingestion rate of copepods are used in the calculation. Potential biomagnification is demonstrated only for Se and Zn in the temperate copepods, whereas for other metals and those in the subtropical copepods, they are biodiminished during their transfer from the primary producers to the copepods. It is clear from such analysis that the $\mathrm{k}_{\mathrm{e}}$ plays a much more important role in the food chain bioaccumulation than the $\mathrm{AE}$ and the ingestion rate of the copepods. The much higher efflux rate of metals in the subtropical species renders a TTF $>1$ impossible. Conversely, TTF $>1$ for $\mathrm{Zn}$ in $T$. longicornis is largely attributed by the relatively low $\mathrm{k}_{\mathrm{e}}$ recorded in this species. Consistent with these predictions, the concentrations of $\mathrm{Zn}$ in phytoplankton collected from coast of Monaco were about $3 \mu \mathrm{g} \mathrm{g}^{-1}$ dry $\mathrm{wt}_{\text {, }}$ and in mixed copepods (Acartia clausi, Centropages typicus, Paracalanus parvus, Clausocalanus sp.) were about $167 \mu \mathrm{g}$ $\mathrm{g}^{-1}$ dry wt (Fisher et al. 2000).

The food chain transfer of metals to fish has not been extensively studied since the early studies in the 1970s by Pentreath and others showed that the dietary uptake of metals indeed dominates metal accumulation in marine fish (Pentreath 1973, 1976, 1977). There were also some earlier studies on the dietary exposure of metals to marine fish (Willis \& Sunda 1984, Dallinger et al. 1997). Pentreath (1976) fed the radiolabeled worm Nereis diversicolor to plaice for $1 \mathrm{~h}$ and then depurated the fishes in non-radioactive water for $34 \mathrm{~d}$. The $\mathrm{Zn}$ AE measured after $5 \mathrm{~d}$ of depuration was $18 \%$. Reinfelder \& Fisher (1994) showed that the AEs for 2 marine fish (Menidia menidia and Menidia beryllina) feeding on marine copepod diets were only $2.7 \%$ for $\mathrm{Cd}$ and $6.2 \%$ for $\mathrm{Zn}$. Metal AEs in a few other fish species have been recently quantified. These measurements in different laboratories using pulse-chase radiolabeling feeding techniques and similar preys have given similar results for different fish species. For example, Ni et al. (2000) found that Cd AEs were 10 to $26 \%$ in the mudskipper Periophthalmus cantonensis

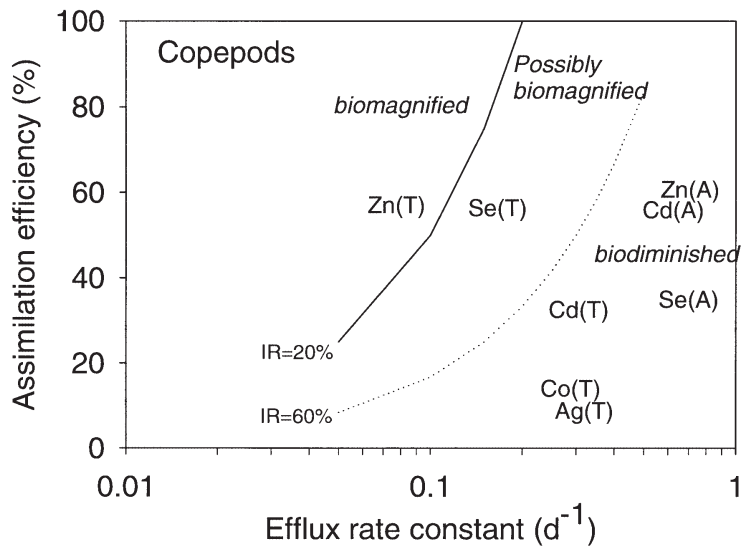

Fig. 1. The predicted potential biomagnification of metals in marine copepods through transfer from prey. Both the low (solid line) and high (dotted line) end of the ingestion rate (IR, as $\%$ body dry wt $\mathrm{d}^{-1}$ ) have been used in the calculation. $\mathrm{T}$ : copepod Temora longicornis (Wang \& Fisher 1998); A: copepod Acartia spinicauda (Xu et al. 2001)

and 14 to $33 \%$ in the glassy fish Ambassis urotaenia when fed on copepods and Artemia. For Zn, the AEs were 11 to $31 \%$ in the mudskipper and 5 to $17 \%$ in the glassy fish. Xu \& Wang (2002b) recently also quantified metal AEs in the mangrove snapper Lutjanus argentimaculatus, a predatory fish, and similarly measured an $\mathrm{AE}$ of 6 to $10 \%$ for $\mathrm{Cd}$ and 15 to $30 \%$ for $\mathrm{Zn}$ when fed copepods, Artemia and clam tissues. Baines et al. (2002) report that the $\mathrm{Cd}$ and $\mathrm{Zn}$ AEs of striped bass (Morone saxatillis) were 23 to 28 and 23 to $40 \%$, respectively, when fed Artemia and copepods.

Of the many elements considered, the AEs of radiocesium and methylmercury in predatory fish are the highest. Zhao et al. (2001) found that radiocesium were assimilated by mangrove snappers Lutjanus argentimaculatus with an efficiency as high as 78 to $96 \%$, whereas the assimilation of Cd was relatively low (6 to $10 \%$ ) for mangrove snappers (Xu \& Wang 2002b). Food quantity appears to greatly affect the metal AE when the level of ingestion is below a certain threshold. For example, the AEs of Cd and Zn increased from 7 to $24 \%$ and from 16 to $43 \%$, respectively, with a decrease in ingestion rate from 0.28 to $0.05 \mathrm{~g} \mathrm{~g}^{-1} \mathrm{~d}^{-1}$. The diets of fish may also be important in determining the metal AE. The AEs of fish from zooplankton were generally lower than those from other animal tissues such as clams or small fish. However, there is little evidence that the metal AEs varied with the trophic levels of the fish. A recent study has indicated that the metal AEs of marine herbivorous fish (e.g. rabbitfish) fed with macroalgae were similar to those measured for planktivorous and piscivorous fish (Chan et al. in press). It thus appears that there is less variation 
among different species of fish with different feeding habitats than among marine invertebrates within the same taxonomic group (e.g. bivalves).

The $\mathrm{k}_{\mathrm{e}} \mathrm{s}$ of metals in fish are comparable to those measured in invertebrates such as mussels (Xu \& Wang 2002). The turnover of these metals in fish was rather moderate, but there was apparently large variation between different metals. The rate constants were 0.025 to $0.047 \mathrm{~d}^{-1}$ for $\mathrm{Cd}$ and $0.015 \mathrm{~d}^{-1}$ for $\mathrm{Zn}$ in the snapper Lutjanus argentimaculatus; these constants were similar to those measured in juvenile striped bass, 0.03 to $0.07 \mathrm{~d}^{-1}$ for $\mathrm{Cd}$ and 0.01 to $0.03 \mathrm{~d}^{-1}$ for $\mathrm{Zn}$ (Baines et al. 2002). The $\mathrm{k}_{\mathrm{e}}$ of Se in snappers (0.027 to $0.031 \mathrm{~d}^{-1}$ ) was similar to that in fathead minnow larvae $\left(0.025 \mathrm{~d}^{-1}\right.$; Bennett et al. 1986), but lower than that measured in juvenile striped bass $\left(0.08\right.$ to $0.09 \mathrm{~d}^{-1}$; Baines et al. 2002). Differences in tissue distribution as a result of different exposure resulted in a difference in the efflux rate for $\mathrm{Cd}$ (higher $\mathrm{k}_{\mathrm{e}}$ after the dietary exposure). Most Cd was distributed in the viscera following uptake from the dietary phase, whereas Cd was evenly distributed in the gills, viscera and other tissues after the fish were exposed to $\mathrm{Cd}$ in the aqueous phase (Xu \& Wang 2002). Harrison \& Klaverkamp (1989) have reported that $\mathrm{Cd}$ taken up by rainbow trout from food was eliminated more quickly than that taken up from water; whereas in lake whitefish, the efflux rates were comparable between the 2 routes of exposure.

Most of the interest in metal transfer in marine fish is probably related to the biomagnification of methylmercury and radiocesium. The TTF in fish can similarly be modeled using the model described in Eq. (2) (Fig. 2).

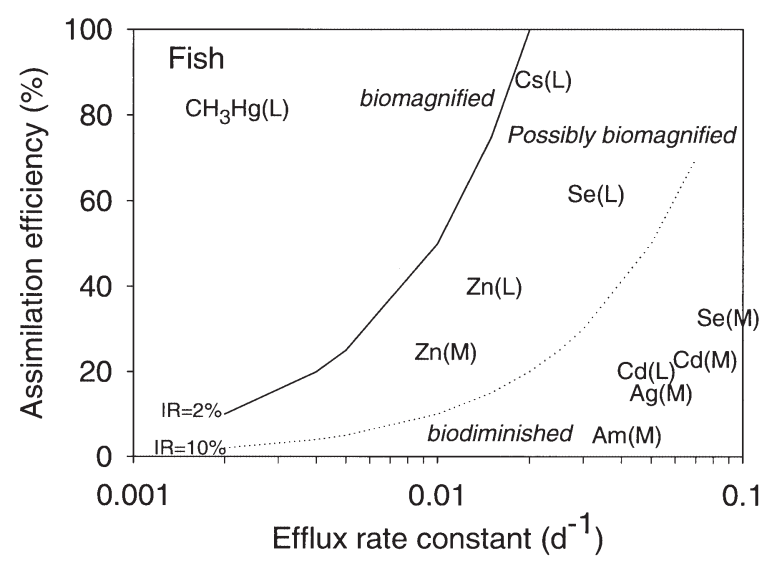

Fig. 2. The predicted potential biomagnification of metals in marine fish through transfer from prey. Both the low (solid line) and high (dotted line) end of the ingestion rate (IR, as \% body dry wt $\mathrm{d}^{-1}$ ) have been used in the calculation. L: mangrove snapper Lutjanus argentimaculatus (Zhao et al. 2001, $\mathrm{Xu} \&$ Wang 2002b). M: small striped bass Morone saxatilis (Baines et al. 2002). $\mathrm{CH}_{3} \mathrm{Hg}$ : data from Trudel \& Rasmussen (1997) and R. Wong \& W. X. Wang (unpubl. data)
Again, both the low $\left(2 \%\right.$ body dry wt $\left.\mathrm{d}^{-1}\right)$ and high $\left(10 \%\right.$ body dry wt $\left.\mathrm{d}^{-1}\right)$ ends of IR were used in the calculation. Several metals such as Cs, Zn and Se are shown to be possibly biomagnified during their transfer to marine fish. It is clear from the analysis that both the AEs and the $\mathrm{k}_{\mathrm{e}}$ of the metals play a very important role in determining the potential biomagnification of metals in the food chain. Suedel et al. (1994) found little evidence of $\mathrm{Cd}$ biomagnification in fish, with a typical TTF of 0.1 to 0.9 , similar to the model prediction $(<0.4$, Xu \& Wang 2002b). The predicted TTF for Cs is about 0.9 to 4.4 and at a medium ingestion rate $(5 \%$ body dry wt $\mathrm{d}^{-1}$ ), the calculation predicts a TTF of 2.0 (Zhao et al. 2001). TTFs measured in the field are consistently 2 to 3 in the piscivorous fish (Rowan \& Rasmussen 1993, Kasamatsu \& Ishikawa 1997). GarnierLaplace et al. (2000) and Baudin et al. (2000) estimated a TTF of 1.45 in the top fish predator in freshwater system. One of the surprising results of the modeling is that the TTF can be close to or higher than 1 for $\mathrm{Zn}$ and Se because of their somewhat high $\mathrm{AE}$ and low $\mathrm{k}_{\mathrm{e}}$. Similarly, Suedel et al. (1994) found a TTF of 0.7 to 1.4 for Se in fish. In contrast, the TTF for Zn in marine fish ranges form 0.26 to 0.68 and in freshwater fish from 0.6 to 1.4 (Suedel et al. 1994). One likely reason for the discrepancy is that fish may regulate $\mathrm{Zn}$ body burdens through the induction of elimination pathways, in which the efflux rate would increase with metal concentration (Reinfelder et al. 1998). However, Chen et al. (2000) have recently demonstrated that the biomagnification factor in zooplankton collected across a metal gradient of lakes in the NE USA was close to 2 for both $\mathrm{Hg}$ and $\mathrm{Zn}$, slightly above 1 for $\mathrm{Cd}$, but less than 1 for As and $\mathrm{Pb}$.

\section{TRANSFER FROM PHYTOPLANKTON TO FILTER- FEEDING BIVALVES AND PREDATORY GASTROPODS}

Metal AEs from the dietary phase have now been routinely quantified in various species of marine bivalve molluscs using the radiotracer pulse-chase feeding technique (Wang \& Fisher 1999). AEs vary greatly with different diets, including various marine phytoplankton and sediment, although such influence is largely species-specific. For example, the metal AEs found for the common mussel Mytilus edulis varied by a factor of 4 (11 to $40 \%$ ) for Cd (Wang \& Fisher 1996), whereas in the green mussel Perna viridis, the AEs of Cd varied by a factor of 2.3 (11 to $25 \%$ ) among different phytoplankton diets tested (Chong \& Wang 2000). It has been generally found that metals associated with green algae (e.g. Chlorella autotrophica and Nanochloris sp.) are the least assimilated by the bivalves, 
primarily because these algae have a rather thick cellulose wall that makes them less digestible (Wang \& Fisher 1996, Chong \& Wang 2000).

The variation of metal AEs among different algal diets has been found to be somewhat smaller than the inter-elemental variation in AE (Wang \& Fisher 1999). For example, the AEs of $\mathrm{Cd}$ and Ag in Mytilus edulis were consistently lower than $40 \%$, whereas the AE of Se was generally higher than $50 \%$. Cr was essentially unavailable to common mussels, with an AE of $<1.5 \%$. There are also substantial variations of metal AEs among different species of marine bivalve mollusks. The AEs of $\mathrm{Cd}, \mathrm{Cr}$, Se and $\mathrm{Zn}$ in the clam Ruditapes philippinarum were found to be consistently higher than in the green mussel Perna viridis feeding on the same diet of phytoplankton under the same feeding conditions. Reinfelder et al. (1997) compared metal AEs in mussels, clams and the oysters, and generally found that the AEs in oysters (Crassostrea virginica) and clams (Macoma balthica and Mercenaria mercenaria) were higher than those in mussels ( $M$. edulis). Ke \& Wang (2001) recently quantified metal AEs in 2 oyster species from estuarine (Crassostrea rivularis) and coastal waters (Ostrea glomerata), and demonstrated that metal AEs were higher in the oysters than in the mussels (e.g. Mytilus edulis, Perna viridis). Such a higher AE contributes at least partly to the higher metal concentrations found in oysters compared to mussels, in additional to the higher influx rate from the dissolved phase and the high ingestion rate due to the very high clearance rate of the oysters (Ke \& Wang 2001). Following initial digestion, metals are mostly assimilated by the oysters without further loss from the body. Ettajani et al. (2001) showed that the oyster Crassostrea gigas retained a lower percentage of the metal associated with the diatom Skeletonema costatum ( $9 \%$, after $21 \mathrm{~d}$ exposure) compared to the prasinophyte Tetraselmis suecica (20\%).

As in many studies on other marine herbivores, the physico-chemical species of metals in the ingested phytoplankton can contribute to variations in metal assimilation from different algal diets. Wang \& Fisher (1996) demonstrated a significant relationship between metal AEs in mussels Mytilus edulis and metal distribution in the cytoplasm of phytoplankton for $\mathrm{Cd}$, Se and Am (and perhaps Ag), but no such relationship was found for $\mathrm{Zn}$, which can be partially regulated by the mussels. They are able to maintain approximately constant body concentration of $\mathrm{Zn}$ under exposure to increasing metal bioavailabilities and hence, uptake rates (Phillips \& Rainbow 1993). Assimilation is an important process by which mussels may regulate the Zn influx. Other processes, such as the GPT (Wang \& Fisher 1996, Chong \& Wang 2000, Ke \& Wang 2001) as well as the partitioning of metals between intestinal and glandular digestion (Decho \& Luoma 1991, 1996) are both important in metal assimilation. These physiological controls (the physiological flexibility of the digestive system) are due, at least in part, to the rather long GPT of metals in the bivalves. Some metals, such as $\mathrm{Co}$ and $\mathrm{Se}$, can be processed for over $2 \mathrm{~d}$ within the bivalve gut (Wang \& Fisher 1996). Furthermore, chemical processes such as metal desorption within the acidic bivalve gut environment may be important for the assimilation of easily exchangeable metals such as Cd, but not for metals that are bound tightly with the cell wall of the algae or are mostly associated with the cytoplasm of the phytoplankton (Wang \& Fisher 1996). Of the many metals studied, desorption appears to control the assimilation of $\mathrm{Cd}$ from ingested particles (Wang \& Fisher 1996). Similarly, Fan \& Wang (2001) showed a significant relationship between Cd assimilation from sediments by the clam Ruditapes philippinarum and its desorption due to lowered acidic gut action, whereas no such significant relationship was found for $\mathrm{Cr}$ and $\mathrm{Zn}$, which have stronger binding affinities with the sediment particles than $\mathrm{Cd}$.

Recent experimental studies have focused on more subtle differences in the food chain transfer of metals 5 as previous studies have extensively focused on the biological properties of phytoplankton (e.g. qualitytype of food particles, quantity-amount of available food, cytosolic distribution), the physiological flexibility exhibited by bivalve molluscs may also play a major role in the transfer of metals to the bivalves. For example, a subtle increase in metal AE when the ingested sediments are purged with phytoplankton was recorded in the green mussel Perna viridis, likely caused by a longer retention of the metals within the digestive tract (Chong \& Wang 2001, Ke \& Wang 2002). There are marked differences among the metals in their assimilation in response to variations in food quality and quantity. Cd assimilation by green mussels has recently been found to be more affected by variations in food type than by food quantity, whereas $\mathrm{Zn}$ assimilation was more affected by food quantity variation than by food quality (R. Wong \& W. X. Wang unpubl. data). Such contrasting behavior in metal assimilation was probably due to the differences in metal geochemistry as well as whether the accumulated metal concentrations can be regulated by the mussels.

The physiology of bivalves also has a substantial influence on metal assimilation. A recent study has demonstrated that $\mathrm{Cd}$ assimilation was increased substantially by pre-exposure of green mussels to $\mathrm{Cd}$, in correlation with an increase in the $\mathrm{Cd}$ tissue burden and the association of the metal with metallothioneinlike proteins (MTLP) (Blackmore \& Wang 2002). In contrast, Zn assimilation was not significantly affected by $\mathrm{Zn}$ pre-exposure, perhaps because of the regulation 
of accumulated $\mathrm{Zn}$ concentrations by the mussels. Most accumulated $\mathrm{Zn}$ was associated with the insoluble fraction in the tissues. In addition to detoxificatory metal binding with metallothionein (MT) and/or granules, which function to maintain metabolically available metal homeostasis, a few metals may be bound in bivalves with insoluble compounds such as sulphide (George et al. 1986, Berthet et al. 1992). These studies indicated that Ag can strongly bind with sulphide in the bivalves. When the mussels were exposed to Ag for an extended period of time, the induction of sulphide resulted in a high assimilation of Ag by the green mussels (D. Shi, G. Blackmore, W. X. Wang unpubl. data). Remarkably, there was no depuration whatsoever by the green mussels following Ag pre-exposure. The induction of sulphide in the mussels was related both to the duration of pre-exposure to Ag and to ambient Ag concentrations. These results suggest that biochemical modification as a result of metal exposure and adaptation can have a substantial influence on metal bioavailability in marine mussels. Because MT can be induced not only by metal exposure (although we have not been able to induce the synthesis of MT in green mussels by Ag exposure; D. Shi, G. Blackmore, W. X. Wang unpubl. data), but also by natural seasonal variations in environmental conditions (Legras et al. 2000), trace metal assimilation by bivalves may also exhibit seasonal variations as a result of MT fluctuation. Ettajani et al. (2001) have demonstrated a positive relationship between MTLP levels and the gross concentration of $\mathrm{Cd}$ in the soft tissues of the oyster Cras-

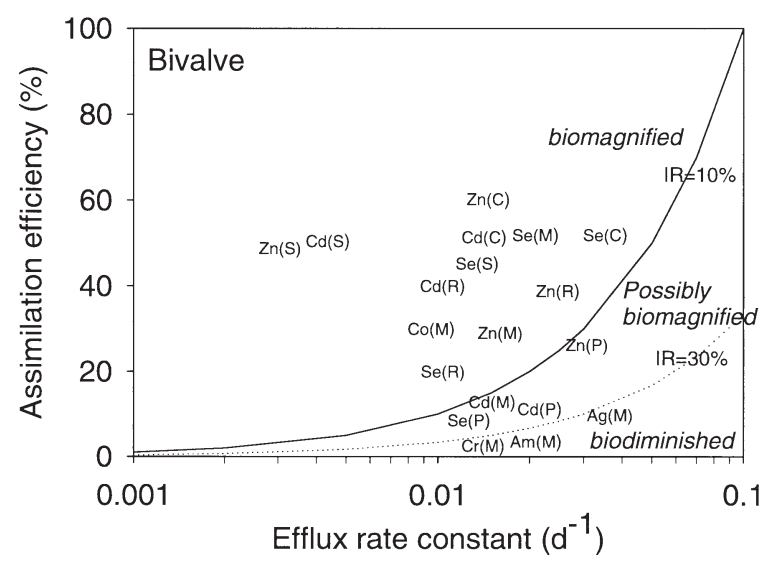

Fig. 3. Predicted potential biomagnification of metals in marine bivalves through transfer from prey. Both the low (solid line) and high (dotted line) end of the ingestion rate (IR, as \% body dry wt $\mathrm{d}^{-1}$ ) have been used in the calculation. M: common mussel Mytilus edulis (Wang et al. 1996a); P: green mussel Perna viridis (Chong \& Wang 2001); R: clam Ruditapes philippinarum (Chong \& Wang 2001); C: oyster Crassostrea rivularis (Ke \& Wang 2001); S: oyster Saccostrea glomerata (Ke \& Wang 2001) sostrea gigas. Such MTLP-bound Cd may potentially be bioavailable to consumers at higher trophic levels.

Trace metal efflux in marine bivalves has been measured in earlier studies using radiotracer techniques (Dahlgaard 1981, 1986, Luoma et al. 1992, Fisher et al. 1996, Wang et al. 1996a). Metal efflux measured in the laboratory and in the field are comparable (Fisher et al. 1996). The $\mathrm{k}_{\mathrm{e}} \mathrm{s}$ in mussels and in clams are typically within 0.01 to $0.03 \mathrm{~d}^{-1}$ (or a turnover of 1 to $3 \%$ tissue burden $\mathrm{d}^{-1}$ ). In mussels, metals that tend to bind with MT (e.g. Cd) are lost at a slower rate than metals that do not bind with MT (e.g. Ag) (Wang et al. 1996a). Such differences are not great, however, and are difficult to detect even using very sensitive radiotracer techniques. Sources of exposure of metals (aqueous and dietary) did not significantly affect the efflux, except for a few metals such as Ag, which may bind differently following different routes of exposure (Wang et al. 1996a).

The high concentrations of $\mathrm{Cu}, \mathrm{Cd}$ and $\mathrm{Zn}$ in oysters may largely be attributable to their much lower efflux rates than in mussels. Ke \& Wang (2001) have recently recorded $\mathrm{a} \mathrm{k}_{\mathrm{e}}$ of 0.003 to $0.004 \mathrm{~d}^{-1}$ for $\mathrm{Cd}$ and $\mathrm{Zn}$ in the coastal oyster Saccostrea glomerata, whereas the efflux of Se was comparable to that found in mussels. The tissue Se burden in mussels and oysters is thus somewhat comparable (O'Connor 1992). A marked difference in the pattern of accumulation of metals to a high level has, however, been documented between estuarine and coastal oysters. For example, the estuarine oyster Crassostrea rivularis achieves a high metal concentration as a result of increased influx from solution at lowered salinity (not solely caused by the physico-chemical change of metal speciation), whereas the $\mathrm{k}_{\mathrm{e}}$ remains comparable to those found in mussels and clams. In contrast, the coastal oyster $S$. glomerata achieves a high metal concentration as a result of reduced efflux rate. These studies again illustrate the rather subtle mechanisms operating in different species of marine bivalves accumulating metals from their living environments.

With a reasonable estimate of the metal AEs and efflux rate, as well as the knowledge of the ingestion rate of the bivalves, which has been gained through extensive studies by bivalve physiological ecologists (Bayne 1993), it is possible to model the likely TTF between phytoplankton and bivalves using Eq. (2) (Fig. 3). Thus, many metals (Cd, Se and $\mathrm{Zn}$ ) are likely to be biomagnified during metal transfer from phytoplankton to bivalves as a result of the high metal AE. Trace metal efflux rates appear to play a less important role than the $\mathrm{AE}$ in leading to a TTF $>1$. For the many metals considered, only Am and $\mathrm{Cr}$ are not biomagnified by the bivalves because of their low AE, despite the fact that their $k_{e}$ is comparable to those of other 
metals in these bivalve species. Consistently, the concentrations of $\mathrm{Cd}$, Se and $\mathrm{Zn}$ in different species of bivalves are higher than those concentrations in marine phytoplankton (summarized in Förstner 1980, Kennish 1997).

Marine gastropods and echinoderms are often the top predators in marine benthic food chains. Gastropods may prey directly on bivalves or barnacles, or scavenge dead animal tissues. One distinct difference between planktonic and benthic top predators is the much higher concentrations of $\mathrm{Cd}, \mathrm{Cu}$ and $\mathrm{Zn}$ in the benthic predatory gastropods. Concentrations of $\mathrm{Cd}$ and Zn can reach as high as 10 and $200 \mu \mathrm{g} \mathrm{g}^{-1}$. Remarkably, Zn concentrations as high as 1800 to $2050 \mathrm{\mu g} \mathrm{g}^{-1}$ have been measured in Morula musiva from Hong Kong coastal waters (Blackmore \& Morton 2001). The gastropods are an important source of seafood in SE Asia; hence, these high metal concentrations have led to local concerns about human dietary exposure. Consistent with these metal concentration measurements, the metal AEs in these predators are generally high. Wang \& Ke (2002) have reported that metal AEs in Babylonia formasae habei and Nassarius teretiusculus are surprisingly high. AEs for Cd as high as $99 \%$ have been measured in B. formasae habei feeding on clam tissue. These AEs are the highest $\mathrm{Cd}$ AEs measured among different marine invertebrates. The AEs of radiocesium in a marine food chain consisting of phytoplankton, bivalves and the predatory gastropod B. formasae habei have also been compared (Wang et al. 2000). The AEs were found to increase from 1 to $10 \%$ in the mussels to 44 to $58 \%$ in the gastropods.

The high AEs of these metals are presumably related to the relative binding of metals in available form, such as MTs in the soft tissues, or in less available forms, such as in the mineralized granules that serve to detoxify metals as an insoluble phosphate salt in gastropods (Langston \& Zhou 1986, 1987, Nott \& Langston 1989, Bebianno \& Langston 1991). MTs are rather abundant under natural conditions in the gastropods (Leung \& Furness 1999). Although these MTs are turned over by the gastropods and may release the metals, these metals may rapidly bind with newly synthesized MTs (Langston et al. 1998). The digestive glands contain spherical intracellular granules with a concentric structure enriched in Mn and Ca (Mason \& Nott 1981). Nott \& Nicolaidou (1989) showed that the high metal concentration in the digestive gland is due to the presence of $\mathrm{Mg}_{3}\left(\mathrm{PO}_{4}\right)_{2}$ in the granules, which serve as a ligand for binding metal ions. Environmental management and risk assessment should therefore consider the physiological forms of the metal sequestration in marine invertebrates and their potential bioavailability to higher trophic levels.
Both the physico-chemical form of metals in the prey and the physiological properties of the predator play a major role in the assimilation of metals. The influence of the tissue specificity of metals in the prey on the transfer of metals to the predator has been considered previously (Nott \& Nicolaidou 1994, Wallace \& Lopez 1997). Nott \& Nicolaidou (1990) fed the carnivorous gastropod Murex trunculus separately with prey gastropod Cerithium vulgatum containing detoxified metals in insoluble granules in the digestive gland, the kidney of scallops and the body tissue of barnacles. The granules passed through the entire length of the gut into the faecal pellets without assimilation. More recently, a study has compared the metal AEs in predatory gastropods feeding on prey (barnacles, mussels and oysters) with different patterns of accumulating metals (G. Blackmore \& W. X. Wang unpubl. data). The accumulated $\mathrm{Zn}$ in the barnacles (mostly below the gut epithelium in the form of phosphate granules) was assimilated by the gastropod with moderate efficiency $(75 \%)$. It is clear from these experiments that insoluble forms of metals in prey may still serve as sources (as well as MT-bound metals) for further transfer to a higher trophic level, instead of acting as a sink for metals during food chain transfer. In a series of studies, Wallace and others have prepared cytosolic and granule-bound $\mathrm{Cd}$ from the oligochaete worm Limnodrilus hoffmeisteri and fed them to shrimp Palaemonetes pugio (Wallace \& Lopez 1996, 1997, Wallace et al. 1998). They demonstrated that the physico-chemical pool of Cd is critical in the assimilation of $\mathrm{Cd}$ by the shrimp, again presumably due to the rather short GPT of metals in the shrimp. There was a 1:1 relationship between the amount and the percentage of $\mathrm{Cd}$ in the oligochaete cytosol and the amount and percentage of Cd absorbed by the shrimp (Wallace \& Lopez 1996). Thus, only metal bound to the soluble fraction of prey (e.g. MTLP) is available to the higher trophic levels, whereas metals bound with metal-rich granules were relatively unavailable (Wallace \& Lopez 1997, Wallace et al. 1998). Factors influencing the subcellular metal distribution and the metal detoxification mechanism in the prey will subsequently alter metal transfer to the predators.

The $\mathrm{k}_{\mathrm{e}}$ in marine gastropods is rather low compared to other invertebrates and may similarly explain the high metal concentration in these animals (Wang \& Ke 2002). Cd and $\mathrm{Zn} \mathrm{k}_{\mathrm{e}} \mathrm{s}$ in 2 gastropods (Nassarius teretiusculus and Babylonia formasae habei) were as low as 0.00113 to $0.0055 \mathrm{~d}^{-1}$, and the biological retention half-lives were as long as 0.265 to $2.41 \mathrm{yr}$. Such a long biological retention half-life $(2.4 \mathrm{yr})$ is one of the longest ever measured in several studies on invertebrates such as bivalves, copepods and barnacles using radiotracer techniques. The $\mathrm{k}_{\mathrm{e}}$ of $\mathrm{Zn}$ in $B$. formasae 
habei $\left(0.0057 \mathrm{~d}^{-1}\right)$ is $2.4 \times$ smaller than its $\mathrm{k}_{\mathrm{e}}$ in $N$. teretiusculus $\left(0.0138 \mathrm{~d}^{-1}\right)$. Again, the long retention of metals in the gastropods may be related to the binding of Cd with MTs in phosphate granules in the digestive glands, which can effectively sequester metals (Nott \& Langston 1989, Langston \& Zhou 1987). Similar binding resulting in an extremely low efflux has been documented in barnacles (Wang et al. 1999, Rainbow \& Wang 2001). Consistent with these observations, extremely low excretion of Cd was found in other species of gastropods (e.g. Littorina littorea, Langston \& Zhou 1987; Biomphalaria glabrata, Guerrero et al. 2000), but Cd was redistributed among different tissues in the animals during the depuration period (Langston \& Zhou 1987, Guerrero et al. 2000). Langston \& Zhou (1987) could not detect any loss of Cd from $L$. littorea during a 7 mo depuration period.

Food chain transfer appears to dominate metal accumulation in the gastropods (Blackmore 2000, Wang \& Ke 2002). Blackmore (2000) provided field evidence of the transfer of metal from invertebrate prey to the intertidal predator Thais clavigera. Gastropods collected from an exposed shore where they fed primarily on barnacles had higher Zn body concentrations than their sheltered shore conspecifics which preyed primarily on mollusks. Conversely, those collected from the sheltered shore have higher $\mathrm{Cu}$ body concentrations than their exposed shore conspecifics because of the higher proportion of hemocyanin-containing gastropods in their diet. Wang \& Ke (2002) modeled the exposure of metals in the gastropods and found that the majority of metals ( $\mathrm{Cd}$ and $\mathrm{Zn}$ ) was derived from the diet. In other predatory benthic invertebrates, a much higher AE (67 to $100 \%$ ) was recorded for the benthic predatory snow crab Chinoecetes opilio (Rouleau et al. 2000). Such a high AE, coupled with an extremely low efflux (the biological retention half-life of $\mathrm{Ag}$ is $>1000 \mathrm{~d}$ ), leads to a high Ag concentration in the snow crab. Rouleau et al. (2000) therefore concluded that predation is the major transfer route for Ag to these marine benthic predators. Dietary exposure may also be important to account for the high concentrations in vertebrate predators in subarctic regions. A close relationship has been shown between high $\mathrm{Cd}$ concentrations in cephalopods and the high $\mathrm{Cd}$ concentrations in whales, suggesting that cephalopods constitute an important source for Cd for their predators at high latitudes (Bustamante et al. 1998).

A model for potential biomagnification of several metals in gastropods is shown in Fig. 4. Both Cd and Zn are predicted to biomagnify during their transfer to gastropods. The ingestion rate of these animals is generally much lower than those of suspension-feeding or deposit-feeding invertebrates. Both the high AE and the low $\mathrm{k}_{\mathrm{e}}$ are responsible for the biomagnification of these 2 metals in gastropods. However, a much higher $\mathrm{AE}$ would be required to yield a TTF $>1$. Radiocesium has the potential to be biomagnified because of its moderately high AE (Wang et al. 2000). This model prediction is consistent with the field observations in several predatory gastropods. For example, Blackmore (2001) showed that the concentrations of $\mathrm{Cd}$ (8.8 to $\left.8.9 \mu \mathrm{g} \mathrm{g}^{-1}\right), \mathrm{Cu}\left(51.8\right.$ to $211 \mu \mathrm{g} \mathrm{g}^{-1}$ ) and $\mathrm{Zn}$ (164 to $314 \mathrm{\mu g} \mathrm{g}^{-1}$ ) in the predatory neogastropoda Thais clavigera and T. luteostoma collected from the shores of Hong Kong were significantly higher than their concentrations in prey bivalves such as mussels Septifer virgatus (6.94, 12.6 and $87 \mu \mathrm{g} \mathrm{g}^{-1}$ for $\mathrm{Cd}, \mathrm{Cu}$ and $\mathrm{Zn}$, respectively). Concentrations of $\mathrm{Cd}$ (10 to $13 \mu \mathrm{g} \mathrm{g}^{-1}$ ) and $\mathrm{Cu}$ (339 to $834 \mu \mathrm{g} \mathrm{g}^{-1}$ ) in these gastropods collected from the sheltered site within the Cape d'Aguilar reserve, Hong Kong, were also much higher than in the prey barnacles (3.4 to $4.6 \mu \mathrm{g} \mathrm{g}^{-1}$ for $\mathrm{Cd}$ and

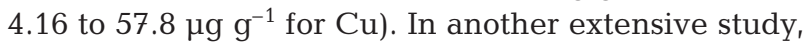
Blackmore (2000) quantified the concentration of $\mathrm{Cd}$, $\mathrm{Cu}$ and $\mathrm{Zn}$ in the common prey of predatory gastropods Thais clavigera. Of all the types of prey considered, Tetraclita squamosa (barnacles), Lunella coronata (gastropods), Tegula argyrostoma (gastropod), Capitulum mitella (barnacle), Saccostrea cucullata (oyster), Balanus amphitrite (barnacle) and Siphonaria japonica (gastropod), the $\mathrm{Cd}$ concentrations ranged between 1 and $6 \mu \mathrm{g} \mathrm{g}^{-1}$, whereas the concentration in the predatory gastropod T. clavigera was 8.1 to $8.2 \mu \mathrm{g}$ $\mathrm{g}^{-1}$. Similarly, in an extensive survey of metal concentrations in various marine organisms in Taiwan from 1991 to 1998 , Jeng et al. (2000) showed that the concentrations of many metals $(\mathrm{Cu}, \mathrm{Zn}, \mathrm{Cd}$ and $\mathrm{As})$ in dif-

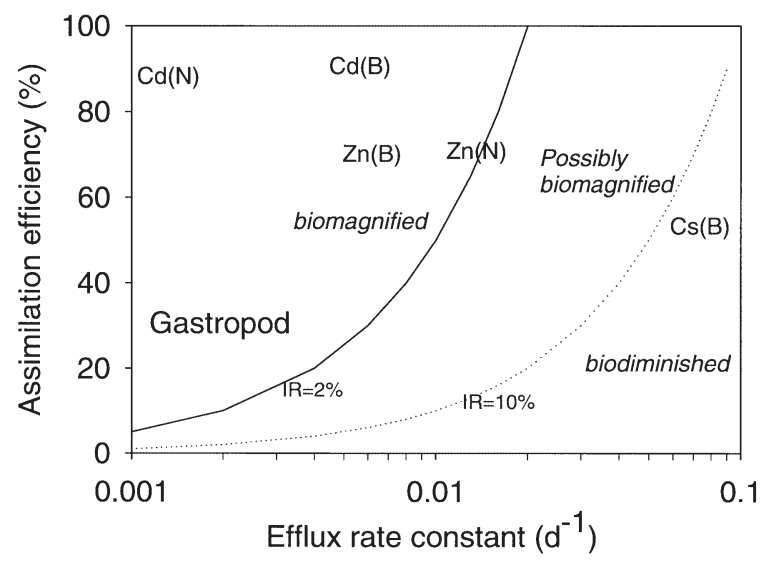

Fig. 4. Predicted potential biomagnification of metals in marine gastropods through transfer from prey. Both the low (solid line) and high (dotted line) end of the ingestion rate (IR, as \% body dry wt $\mathrm{d}^{-1}$ ) have been used in the calculation. B: Babylonia formasae habei (Wang et al. 2000, Wang \& Ke 2002); N: Nassarius teretiusculus (Wang \& Ke 2002) 
ferent species of gastropods were generally the highest among many benthic organisms collected (mussels, clams, oysters, crabs and shrimps). Because of the potential dominance of dietary metal uptake and the relatively high TTF in gastropods, the bioconcentration factor $(\mathrm{BCF})$, calculated as the ratio of metal concentrations in the animals to metal concentration in the aqueous phase (e.g. dissolved exposure), may have underestimated the potential bioaccumulation of metals. It is thus clear from these analyses that hazard assessment applying the BCF approach to estimate the bioaccumulation potential of metals should incorporate the dietary uptake pathways, especially for those predatory invertebrates and fish.

\section{SUMMARY AND FUTURE RESEARCH}

Over the past decade, the study of the food chain transfer of metal contaminants in marine food webs has made substantial progress for several reasons. Dietary exposure is now considered as a major route for metal accumulation in marine animals, including both invertebrates and fish. In the many marine animals that are known to accumulate a phenomenal amount of metal, dietary exposure is often the predominant route for this accumulation. There are probably few marine organisms that can accumulate metals to a phenomenal concentration through uptake from the aqueous phase. Development of novel techniques and an appreciation of the complexity of metal biology have also been critical in leading to these extensive studies. Among a few metals that have been extensively studied, Cd shows by far the clearest patterns. However, metals differ tremendously in their chemical and biological behavior in aquatic systems. For example, Zn can be regulated by many aquatic invertebrates, and its physico-chemical and biological properties are different from those of Cd. Furthermore, emerging environmental problems in many developed and developing countries warrant urgency in the study of the behavior of these metals in marine ecosystems (Wang 2002). When metal concentrations were quantified recently in an extremely contaminated Chinese bay, Zn concentrations in these sediments were found to be as high as $1 \%$ of the total sediment dry weight (Fan et al. in press). As a result of severe metal contamination, several $\mathrm{km}^{2}$ in the area were found to contain no organisms whatsoever.

Extensive studies on the food chain transfer of metals have demonstrated that the physico-chemical species is important in transfer processes; however, our current knowledge is mostly based on the physico-chemical properties of metals (Table 1). This is not surprising when considering the whole research field of metal-
Table 1. Processes controlling the food chain transfer of metals from prey to a higher trophic level

\begin{tabular}{|ll|}
\hline Prey & Predator \\
\hline Physico-chemical species & Sequestration \\
Cytoplasmic & Metal-rich granule \\
Metal-rich granules & Metalloprotein \\
Sulphide & Sulphide \\
Metalloprotein & Homeostasis \\
Subcellular & Body burden \\
Food characteristics & Pre-exposure \\
Quantity & Adaptation/tolerance \\
Quality & Detoxification \\
Nutrient stoichiometry & Digestive/feeding physiology \\
Metal concentration & Prey selectivity \\
& Digestive enzyme/partitioning \\
& Ingestion rate \\
& Gut passage \\
& Optimal foraging \\
\hline
\end{tabular}

biota interaction, which is dominated by the free ion activity model first developed in the 1970s (Campbell 1995). The free ion activity model, in fact, has been the guiding principle in understanding metal bioavailability and toxicity to aquatic organisms. Over the past $10 \mathrm{yr}$ or so, studies in the particulate phase have identified analogous species (e.g. cytoplasmic metals in the phytoplankton, easily exchangeable metals in the sediments) controlling metal bioavailability from the particulate phase. These studies have clearly supplemented the free ion activity model in reinforcing the view that metal physico-chemical properties influence metal bioavailability. Thus, the bioavailability and toxicity of metals depend not only on their gross concentration, but also on their physico-chemical form. At each trophic level, it is necessary to examine a metal's distribution in different bioreactive and nonbioreactive forms. Therefore, the chemical stability of the compounds permits the prediction of their biological activity (Amiard-Triquet et al. 1992, 1993, Ettajani et al. 2001). Whether the biological reactivity of the metals in the predator will affect metal transfer remains to be further studied (Table 1).

This leads us to the question: What is the next step in light of the substantial progress made in recent years? Marine invertebrates have developed remarkable and diverse strategies in accumulating metals (e.g. granules, MT, sulphide). The controls of the binding of accumulated metals on trophic transfer still need to be revealed. More importantly, a more flexible approach for studying the interaction between metals and biota is needed. Although there are now guiding principles (e.g. physico-chemical species) in the field, there is clearly a need for a paradigm shift, with a focus on the mechanisms of physiological and biochemical controls 
on metal bioavailability. Such controls can be very organism-specific and the biology should be the highlights in these studies. Subtle physiological and biochemical mechanisms affecting metal transfer should be revealed. Among the 3 parameters determining metal TTF, the ingestion rates of animals still remain difficult to predict, and only a low and a high range for the ingestion rate can be estimated. Feeding activity is a function of food quantity, quality and prey selectivity, and as such, the TTF is probably variable. All 3 parameters described in the model can be prey-specific, and thus, the prey type and selection will have a major impact on the trophic transfer of metals in aquatic food webs. How the feeding physiology of aquatic animals, such as the optimization of energy gain (e.g. optimal foraging), can affect metal contaminant transfer remains to be further examined.

Most of the metal bioavailability studies employed populations which had originated from relatively clean marine environments. Whether the kinetic parameters such as metal AE and efflux rate will vary in populations living in contaminated environments remains, at present, mostly speculative. The outcome of these variations will of course affect the prediction of TTF; thus, there is a possibility that TTF from contaminated environments may differ from those in clean environments as predicted in this study. Recent laboratory and field studies have found that a few marine bivalve species are able to modify their biochemistry and physiology in response to metal contamination. Hence, there was a great variation of metal $\mathrm{AE}$ and influx from the aqueous phase in these 'contaminated' populations (Blackmore \& Wang 2002, D. Shi \& W. X. Wang unpubl. data). We have recently found that clams (Mactra veneriformis and Ruditapes philippinarum) collected from a $\mathrm{Cd}$ contaminated bay (where Cd concentrations in the tissues reached as high as $8 \mu \mathrm{g} \mathrm{g}^{-1}$ ) had distinguishably higher Cd AEs as compared to populations collected from less contaminated or clean sites. In cotrast, there was no major difference in Cd efflux from the clams among the different sites (D. Shi \& W. X. Wang unpubl.). Accordingly, the concentrations of MTs in these 'contaminated' populations were much higher. Clearly, studies in the contaminated areas may reveal exciting patterns in metal handling strategies and their influences on metal bioavailability.

Generally, the trophic level in the food chain does not predict metal bioavailability and biomagnification (Amiard-Triquet et al. 1992). The complexity of food chain interaction should be considered in studying the complicated food chain transfer of metals in contrasting marine food webs. Although biomagnification typically involves at least 3 trophic levels, it is suggested that a more realistic approach is to look at 2 levels at a time. Stable isotope analysis of the trophic status (e.g. $\delta^{13} C_{,} \delta^{15} N_{\text {; }}$ Post 2002) with concurrent measurements of metal concentrations in different trophic levels may reveal patterns of metal transfer, at least for a few metals such as $\mathrm{Hg}$ and $\mathrm{Zn}$. There is also a great need to examine the variability of TTF, which is analogous to the bioconcentration factor used to quantify the extend to which a metal is concentrated by the organisms from the ambient water. Although the uptake rate constant of metals from the soluble phase can now be routinely measured (Luoma \& Fisher 1997), prediction of the uptake rate constant from the prey source, which is a combination of metal $\mathrm{AE}$ and ingestion rate, will be challenging.

Acknowledgements. I am very grateful to Prof. Phil Rainbow and several anonymous reviewers for their critical and stimulating comments on this paper, and to Drs. Nick Fisher and Sam Luoma for their previous advice, which has significantly influenced my view on the food chain transfer of metals. Many people working in my laboratory are thanked for their tireless efforts. This study was supported by several Competitive Earmarked Research Grants from the Hong Kong Research Grants Council (HKUST6108/00M, HKUST6113/ 00M and HKUST6118/01M, N_HKUST603/01, HKUST6097/ 02M) awarded to W.X.W.

\section{LITERATURE CITED}

Amiard-Triquet C, Metayer C, Amiard JC (1980) Study of the transfer of $\mathrm{Cd}, \mathrm{Pb}, \mathrm{Cu}$ and $\mathrm{Zn}$ in neritic and estuarine trophic levels. 2. Bioaccumulation in plankton feeder fish. Water Res 14:1327-1332

Amiard-Triquet C, Martoja R, Marcaillou C (1992) Alternative methodologies for predicting metal transfer in marine food webs including filter-feeders. Water Environ Technol 25: 197-204

Amiard-Triquet C, Jeantet AY, Berthet B (1993) Metal transfer in marine food chains: bioaccumulation and toxicity. Acta Biol Hung 44:387-409

Baines SB, Fisher NS, Stewart R (2002) Assimilation and retention of selenium and other trace elements from crustacean food by juvenile striped bass (Morone saxatilis). Limnol Oceanogr 47:646-655

Barka S, Pavillon JF, Amiard JC (2001) Influence of different essential and non-essential metals on MTLP levels in the copepod Tigriopus brevicornis. Comp Biochem Physiol C 128:479-493

Baudin JP, Adam C, Garnier-Laplace J (2000) Dietary uptake, retention and tissue distribution of ${ }^{54} \mathrm{Mn},{ }^{60} \mathrm{Co}$ and ${ }^{137} \mathrm{Cs}$ in the rainbow trout (Oncorhynchus mikiss Walbaum). Water Res 34:2869-2878

Bayne BL (1993) Feeding physiology of bivalves: timedependence and compensation for changes in food availability. In: Dame RF (ed) Bivalve filter feeders in estuarine and coastal ecosystem processes. Springer-Verlag, Berlin, p 1-24

Bebianno MJ, Langston WJ (1991) Metallothionein induction in Mytilus edulis exposed to cadmium. Mar Biol 108:91-96

Bennett WN, Brooks AS, Boraas ME (1986) Selenium uptake and transfer in an aquatic food chain and its effects on fathead minnow larvae. Arch Environ Contam Toxicol 15: $513-517$ 
Berthet B, Amiard JC, Amiard-Triquet C, Martoja M, Jeantet AY (1992) Bioaccumulation, toxicity and physicochemical speciation of silver in bivalve mollusks: ecotoxicological and health consequences. Sci Total Environ 125:97-122

Blackmore G (2000) Field evidence of metal transfer from invertebrate prey to an intertidal predator, Thais clavigera (Gastropod: Muricidae). Estuar Coast Shelf Sci 51: 127-139

Blackmore G (2001) Interspecific variation in heavy metal body concentrations in Hong Kong marine invertebrates. Environ Pollut 114:303-311

Blackmore G, Morton B (2001) The interpretation of body trace metal concentration in neogastropods from Hong Kong. Mar Pollut Bull 42:1161-1168

Blackmore G, Wang WX (2002) Uptake and efflux of Cd and Zn by the green mussel Perna viridis after metal preexposure. Environ Sci Technol 36:989-995

Bryan GW (1979) Bioaccumulation of marine pollutants. Phil Trans R Soc Lond B 286:483-505

Bryan GW (1984) Pollution due to heavy metals and their compounds. In: Kinne O (ed) Marine ecology, Vol 5. John Wiley \& Sons, Chichester, p 1289-1430

Bustamante P, Caurant F, Fowler SW, Miramand P (1998) Cephalopods as a vector for the transfer of cadmium to top marine predators in the north-east Atlantic Ocean. Sci Total Environ 220:71-80

Campbell PGC (1995) A critique of the free-ion activity model. In: Tessier A, Turner DR (eds) Metal speciation and bioavailability in aquatic systems. John Wiley \& Sons, Chichester, p 45-102

Chan SM, Wang WX, Ni IH (in press) The uptake of Cd, Cr, and $\mathrm{Zn}$ by the macroalga Enteromorpha crinita and subsequent transfer to the marine herbivorous rabbitfish, Siganus canaliculatus. Arch Environ Contam Toxicol

Chang SII, Reinfelder JR (2000) Bioaccumulation, subcellular distribution, and trophic transfer of copper in a coastal marine diatom. Environ Sci Technol 34:4931-4935

Chang SII, Reinfelder JR (2002) Relative importance of dissolved versus trophic bioaccumulation of copper in marine copepods. Mar Ecol Prog Ser 231:179-186

Chen CY, Flot CL (2000) Bioaccumulation and diminution of arsenic and lead in a freshwater food web. Environ Sci Technol 34:3878-3884

Chen CY, Stemberger RS, Klaue B, Blum JD, Pickhardt PC, Folt CL (2000) Accumulation of heavy metals in food web components across a gradient of lakes. Limnol Oceanogr 45:1525-1536

Chong K, Wang WX (2000) Assimilation of Cd, Cr, and Zn by the green mussel Perna viridis and the clam Ruditapes philippinarum. Environ Toxicol Chem 19:1660-1667

Chong K, Wang WX (2001) Comparative studies on the biokinetics of $\mathrm{Cd}, \mathrm{Cr}$, and $\mathrm{Zn}$ in the green mussel Perna viridis and the Manila clam Ruditapes philippinarum. Environ Pollut 115:107-121

Dahlgaard H (1981) Loss of ${ }^{51} \mathrm{Cr},{ }^{54} \mathrm{Mn},{ }^{57} \mathrm{Co},{ }^{59} \mathrm{Fe}^{6}{ }^{65} \mathrm{Zn}$ and ${ }^{134} \mathrm{Cs}$ by the mussel Mytilus edulis. In: International Atomic Energy Agency (ed) Proc Symp Impacts Radionuclide Releases Mar Environ. IAEA, Vienna, p 361-370

Dahlgaard H (1986) Effects of season and temperature on long-term in situ loss rates of $\mathrm{Pu}, \mathrm{Am}, \mathrm{Np}, \mathrm{Eu}, \mathrm{Ce}, \mathrm{Ag}, \mathrm{Tc}$, $\mathrm{Zn}, \mathrm{Co}$ and $\mathrm{Mn}$ in a Baltic Mytilus edulis population. Mar Ecol Prog Ser 33:157-165

Dallinger R, Prosi F, Segner H, Back H (1987) Contaminated food and uptake of heavy metals by fish: a review and a proposal for further research. Oecologia 73:91-98

Decho AW, Luoma SN (1991) Time-courses in the retention of food material in the bivalves Potamocorbula amurensis and Macoma balthica: significance to the absorption of carbon and chromium. Mar Ecol Prog Ser 78:303-314

Decho AW, Luoma SN (1996) Flexible digestive strategies and trace metal assimilation in marine bivalves. Limnol Oceanogr 41:568-572

Eisler R (1981) Trace metal concentrations in marine organisms. Pergamon Press, New York

Ettajani H, Pirastru L (1992) Methodology to predict heavy metals transfer in marine food chains. Hydroecol Appl 4: 79-90

Ettajani H, Berthet B, Amiard JC, Chevolot L (2001) Determination of cadmium partitioning in microalgae and oysters: contribution to the assessment of trophic transfer. Arch Environ Contam Toxicol 40:209-221

Fan W, Wang WX (2001) Sediment geochemical control on $\mathrm{Cd}, \mathrm{Cr}$, and Zn assimilation by the clam Ruditapes philippinarum. Environ Toxicol Chem 20:2309-2317

Fan W, Wang WX, Chen J (in press) Speciation of Cd, Cr, and $\mathrm{Zn}$ in contaminated sediments and its influences on assimilation by marine bivalves. Environ Sci Technol

Fisher NS, Reinfelder JR (1991) Assimilation of selenium in the marine copepod Acartia tonsa studied with a radiotracer ratio method. Mar Ecol Prog Ser 70:157-164

Fisher NS, Reinfelder JR (1995) The trophic transfer of metals in marine systems. In: Turner DR, Tessier A (eds) Metal speciation and bioavailability in aquatic systems. John Wiley \& Sons, Chichester, p 363-406

Fisher NS, Teyssié JL, Fowler SW, Wang WX (1996) The accumulation and retention of metals in mussel from food and water: a comparison of field and laboratory conditions. Environ Sci Technol 30:3232-3242

Fisher NS, Stupakoff I, Sanudo-Wilhelmy SA, Wang WX, Teyssie JL, Fowler SW, Crusius J (2000) Trace metals in marine copepods: a field test of a bioaccumulation model coupled to laboratory uptake kinetics data. Mar Ecol Prog Ser 194:211-218

Förstner U (1980) Inorganic pollutants, particularly heavy metals in estuaries. In: Olausson E, Cato I (eds) Chemistry and biogeochemistry of estuaries. John Wiley \& Sons, Chichester, p 307-348

Fowler SW (1982) Biological transfer and transport processes. In: Kullenberg $\mathrm{G}$ (ed) Pollutant transfer and transport in the Sea, Vol 2. CRC Press, Boca Raton, FL, p 1-65

Fowler SW (1985) Heavy metal and radionuclide transfer and transport by marine organisms. Symp Biol Hung 29: 191-206

Garnier-Laplace J, Adam C, Baudin JP (2000) Experimental kinetic rates of food-chain and waterborne radionuclide transfer to freshwater fish: a basis for the construction of fish contamination charts. Arch Environ Contam Toxicol 39:133-144

George SG, Pirie BJS, Calabrese A, Nelson DA (1986) Biochemical and ultra-structural observations of long-term silver accumulation in the mussel Mytilus edulis. Mar Environ Res 18:255-265

Guerrero NRV, Nahabedian DE, Wider EA (2000) Analysis of some factors that may modify the bioavailability of cadmium and lead by Biomphalaria glabrata. Environ Toxicol Chem 19:2762-2768

Harrison SE, Klaverkamp JF (1989) Uptake, elimination and tissue distribution of dietary and aqueous cadmium by rainbow trout (Salmo gairdneri Richardson) and lake whitefish (Coregonus clupeaformis Mitchill). Environ Toxicol Chem 8:87-97

Hodson PV (1980) Why inorganic metals do not increase in concentration up the food chain. Thalassia Jugosl 16 $327-333$ 
Hutchins DA, Wang WX, Fisher NS (1995) Copepods grazing and the biogeochemical fate of diatom iron. Limnol Oceanogr 40:989-994

Jeng MS, Heng WL, Hung TC, Yeh CY, Tseng RJ, Meng PJ, Han BC (2000) Mussel watch: a review of $\mathrm{Cu}$ and other metals in various marine organisms in Taiwan, 1991-1998. Environ Pollut 110:207-215

Kasamatsu F, Ishikawa Y (1997) Natural variation of radionuclide ${ }^{137} \mathrm{Cs}$ concentration in marine organisms with special reference to the effect of food habits and trophic level. Mar Ecol Prog Ser 160:109-120

Ke C, Wang WX (2001) Bioaccumulation of metals (Cd, Se, and $\mathrm{Zn}$ ) in an estuarine oyster and a coastal oyster. Aquat Toxicol 56:33-51

Kennish MJ (1997) Practical handbook of estuarine and marine pollution. CRC Press, Boca Raton, FL

Landrum PF, Lee H II, Lydy MJ (1992) Toxicokinetics in aquatic systems: model comparisons and use in hazard assessment. Environ Toxicol Chem 11:1709-1725

Langston WJ, Zhou MJ (1986) Evaluation of the significance of metal-binding proteins in the gastropod Littorina littorea. Mar Biol 92:505-515

Langston WJ, Zhou MJ (1987) Cadmium accumulation, distribution and elimination in the bivalve Macoma balthica: neither metallothionein nor metallothionein-like proteins are involved. Mar Environ Res 21:225-237

Langston WJ, Bebianno MJ, Burt GR (1998) Metal handling strategies in mollusks. In: Langston WJ, Bebianno MJ (eds) Metal metabolism in aquatic environments. Chapman \& Hall, London, p 219-283

Legras S, Mouneyrac C, Amiard JC, Amiard-Triquet C, Rainbow PS (2000) Changes in metallothionein concentrations in response to variation in natural factors (salinity, sex, weight) and metal contamination in crabs from a metal rich estuary. J Exp Mar Biol Ecol 246:259-279

Leung KMY, Furness RW (1999) Effect of animal size on concentrations of metallothionein and metals in periwinkles Littorina littorea collected from the Firth of Clyde, Scotland. Mar Pollut Bull 39:1-12

Luoma SN, Fisher NS (1997) Uncertainties in assessing contaminant exposure from sediments. In: Ingersoll CG, Dillon $\mathrm{T}$, Biddinger GR (eds) Ecological risk assessment of contaminated sediments. Society of Environmental Toxicology and Chemistry Spec Publ Series, Pensacola, FL, p 211-237

Luoma SN, Johns C, Fisher NS, Steinberg NS, Oremland RS, Reinfelder JR (1992) Determination of selenium bioavailability to a benthic bivalve from particulate and solute pathways. Environ Sci Technol 26:485-492

Mason AZ, Nott JA (1981) The role of intracellular biomineralized granules in the regulation and detoxification of metals in gastropods with special reference to the marine prosobranchia Littorina littorea. Aquat Toxicol 1:239-256

Newman MC (1995) Quantitative methods in aquatic ecotoxicology. Lewis Publishers, Boca Raton, FL

Ni IH, Wang WX, Tam YK (2000) The transfer of Cd, Cr, and Zn from zooplankton to mudskipper and glassy fishes. Mar Ecol Prog Ser 194:203-210

Nott JA (1998) Metals and marine food chains. In: Langston WJ, Bebianno MJ (eds) Metal metabolism in aquatic environments. Chapman \& Hall, London, p 387-414

Nott JA, Langston WJ (1989) Cadmium and the phosphate granules in Littorina littorea. J Mar Biol Assoc UK 69: 219-227

Nott JA, Nicolaidou A (1989) Metals in gastropods: metabolism and bioreduction. Mar Environ Res 28:201-205

Nott JA, Nicolaidou A (1990) Transfer of metal detoxifica- tion along marine food chains. J Mar Biol Assoc UK 70: 905-912

Nott JA, Nicolaidou A (1994) Variable transfer of detoxified metals from snails to hermit crabs in marine food chains. Mar Biol 120:369-377

O'Connor TP (1992) Recent trends in coastal environmental quality: results from the first five years of the NOAA Mussel Watch Project. US Dept Commerce, NOAA, National Ocean Service, Washington, DC, p 46

Pentreath RJ (1973) The accumulation and retention of ${ }^{65} \mathrm{Zn}$ and ${ }^{54} \mathrm{Mn}$ by the plaice, Pleuronectes platessa L. J Exp Mar Biol Ecol 12:1-18

Pentreath RJ (1976) Some further studies on the accumulation and retention of ${ }^{65} \mathrm{Zn}$ and ${ }^{54} \mathrm{Mn}$ by the plaice, Pleuronectes platessa L. J Exp Mar Biol Ecol 21:179-189

Pentreath RJ (1977) Radionuclides in marine fish. Oceanogr Mar Biol Annu Rev 15:365-460

Phillips DJH, Rainbow PS (1993) Biomonitoring of trace aquatic contaminants. Elsevier Applied Science, London

Post DM (2002) Using stable isotopes to estimate trophic position: models, methods, and assumptions. Ecology 83: $703-718$

Rainbow PS (1989) Copper, cadmium and zinc concentrations in oceanic amphipod and euphausiid crustaceans, as a source of heavy metals to pelagic seabirds. Mar Biol 103: 513-518

Rainbow PS (1993) The significance of trace metal concentrations in marine invertebrates. In: Dallinger R, Rainbow PS (eds) Ecotoxicology of metals in invertebrates. Lewis Publishers, Boca Raton, FL, p 4-23

Rainbow PS, Wang WX (2001) Comparative assimilation of $\mathrm{Cd}, \mathrm{Cr}, \mathrm{Se}$, and $\mathrm{Zn}$ by the barnacle Elminius modestus from phytoplankton and zooplankton diets. Mar Ecol Prog Ser 218:239-248

Reinfelder JR, Fisher NS (1991) The assimilation of elements ingested by marine copepods. Science 251:794-796

Reinfelder JR, Fisher NS (1994) Retention of elements absorbed by juvenile fish (Menidia menidia, Menidia beryllina) from zooplankton prey. Limnol Oceanogr 39:1783-1789

Reinfelder JR, Wang WX, Luoma SN, Fisher NS (1997) Assimilation efficiencies and turnover rates of trace elements in marine bivalves: a comparison of oysters, clams, and mussels. Mar Biol 129:443-452

Reinfelder JR, Fisher NS, Luoma SN, Nichols JW, Wang WX (1998) Trace element trophic transfer in aquatic organisms: a critique of the kinetic model approach. Sci Total Environ 219:117-135

Ridout PS, Willcocks DA, Morris RJ, White SL, Rainbow PS (1985) Concentrations of $\mathrm{Mn}, \mathrm{Fe}, \mathrm{Cu}, \mathrm{Zn}$ and $\mathrm{Cd}$ in the mesopelagic decapod Systellaspis debilis from the east Atlantic Ocean. Mar Biol 87:285-288

Ritterhoff J, Zauke GP (1997) Evaluation of trace metal toxicokinetics in Greenland Sea copepod and amphipod collected from semi-static experiments on board ship. Polar Biol 17:242-250

Rouleau C, Gobeil C, Tjaelve H (2000) Accumulation of silver from the diet in two marine benthic predators: the snow crab (Chionoecetes opilio) and American plaice (Hippoglossoides platessoides). Environ Toxicol Chem 19:631-637

Rowan DJ, Rasmussen JB (1993) Bioaccumulation of radiocesium by fish: the influence of physicochemical factors and trophic structure. Can J Fish Aquat Sci 51:2388-2410

Spacie A, Hamelink (1985) Bioaccumulation. In: Rand GM, Petrocelli SR (eds) Fundamentals of aquatic toxicology: methods and applications. Taylor \& Francis, Washington, DC, p 1052-1082

Stemberger RS, Chen CY (1998) Fish tissue metals and zoo- 
plankton assemblages of northeastern US lakes. Can J Fish Aquat Sci 55:339-352

Suedel BC, Boraczek JA, Peddicord RK, Clifford PA, Dillon TM (1994) Trophic transfer and biomagnification potential of contaminants in aquatic ecosystems. Rev Environ Contam Toxicol 136:21-89

Thomann RV (1981) Equilibrium model of the fate of microcontaminants in diverse aquatic food chains. Can J Fish Aquat Sci 38:280-296

Trudel M, Rasmussen JB (1997) Modeling the elimination of mercury by fish. Environ Sci Technol 31:1716-1722

Wallace WG, Lopez GR (1996) Relationship between subcellular cadmium distribution in prey and cadmium trophic transfer to a predator. Estuaries 19:923-930

Wallace WG, Lopez GR (1997) Bioavailability of biologically sequestered cadmium and the implications of metal detoxification. Mar Ecol Prog Ser 147:149-157

Wallace WG, Lopez GR, Levinton JS (1998) Cadmium resistance in an oligochaete and its effect on cadmium trophic transfer to an omnivorous shrimp. Mar Ecol Prog Ser 172: 225-237

Wang WX (2002) Putting western pollution problems in perspective-problems in China. SETAC Global 3(2):21-23

Wang WX, Fisher NS (1996) Assimilation of trace elements and carbon by the mussel Mytilus edulis: effects of food composition. Limnol Oceanogr 41:197-207

Wang WX, Fisher NS (1998) Accumulation of trace elements in a marine copepod. Limnol Oceanogr 43:273-283

Wang WX, Fisher NS (1999) Assimilation efficiencies of chemical contaminants in aquatic invertebrates: a synthesis. Environ Toxicol Chem 18:2034-2045

Wang WX, Ke C (2002) Dominance of dietary intake of cadmium and zinc by two marine predatory gastropods. Aquat Toxicol 56:153-165

Editorial responsibility: Otto Kinne (Editor),

Oldendorf/Luhe, Germany
Wang WX, Fisher NS, Luoma SN (1996a) Kinetic determinations of trace element bioaccumulation in the mussel Mytilus edulis. Mar Ecol Prog Ser 140:91-113

Wang WX, Reinfelder JR, Lee BG, Fisher NS (1996b) Assimilation and regeneration of trace elements by marine copepods. Limnol Oceanogr 41:70-81

Wang WX, Qiu JW, Qian PY (1999) Significance of trophic transfer in predicting the high concentration of zinc in barnacles. Environ Sci Technol 33:2905-2909

Wang WX, Ke CH, Yu KN, Lam PKS (2000) Modeling the bioaccumulation of radiocesium in a marine food chain. Mar Ecol Prog Ser 208:41-50

White SL, Rainbow PS (1987) Heavy metal concentrations and size effects in the mesopelagic decapod crustacean Systellaspis debilis. Mar Ecol Prog Ser 37:147-151

Willis JN, Sunda WG (1984) Relative contributions of food and water in the accumulation of zinc by two species of marine fish. Mar Biol 80:273-279

Xu Y, Wang WX (2001) Individual responses of metal assimilation and regeneration by copepod Calanus sinicus to changes in food quantity. Mar Ecol Prog Ser 218:227-238

Xu Y, Wang WX (2002a) The assimilation of detritus-bound metals by marine copepod Acartia spinicauda. Limnol Oceanogr 47:604-610

Xu Y, Wang WX (2002b) Exposure and food chain transfer factor of $\mathrm{Cd}$, Se, and $\mathrm{Zn}$ in a marine fish, Lutjanus argentimaculatus. Mar Ecol Prog Ser 238:173-186

Xu Y, Wang WX, Hsieh DPH (2001) Influences of metal concentration in phytoplankton and seawater on metal assimilation and elimination in marine copepods. Environ Toxicol Chem 20:1067-1077

Zhao X, Wang WX, Yu KN, Lam PKS (2001) Biomagnification of radiocesium in a top marine fish predator. Mar Ecol Prog Ser 222:227-237

Submitted: February 25, 2002; Accepted: August 28, 2002

Proofs received from author(s): October 28, 2002 